\title{
Detection of Leishmania DNA in phlebotomines captured in Campo Grande, Mato Grosso do Sul, Brazil
}

\author{
Elaine A. Silva ${ }^{a}$, Renato Andreotti ${ }^{b, *}$, Edelberto S. Dias ${ }^{c}$, Jacqueline C. Barros ${ }^{\text {b }}$, Julia C.M. Brazuna ${ }^{a}$ \\ a Centro de Controle de Zoonoses, Secretaria Municipal de Saúde, Campo Grande, MS, Brazil \\ ${ }^{\mathrm{b}}$ Embrapa Gado de Corte, BR 262, km 4, Caixa Postal 154, Campo Grande, MS 79002-970, Brazil \\ ${ }^{c}$ Laboratório de Leishmanioses, Centro de Pesquisas René Rachou, Fundação Oswaldo Cruz, Belo Horizonte, MG, Brazil
}

\section{A R T I C L E I N F O}

\section{Article history:}

Received 23 October 2007

Received in revised form 11 March 2008

Accepted 13 March 2008

Available online 30 March 2008

Index Descriptors and Abbreviations:

Leishmania

DNA

Phlebotomines

Vector

\begin{abstract}
A B S T R A C T
Over the past years, leishmaniases have become a public health issue in the Brazilian state of Mato Grosso do Sul, particularly in Campo Grande, the state capital. The purpose of this study was to detect the presence of Leishmania DNA in the population of phlebotomine sandflies using DNA amplification by PCR. Insect captures were carried out from $4 \mathrm{pm}$. to $7 \mathrm{am}$ for 4 consecutive days each month from October 2005 to September 2006 in 16 neighborhoods located in 7 urban regions of Campo Grande. Traps were placed indoors and in the vicinity of households. As many as 971 males and 203 females were collected. One hundred and five naturally fed females were identified and grouped as 1 - to 4 -specimen pools. DNA extraction was carried out using whole insects. Lutzomyia longipalpis predominated, accounting for 99.15\% of the phlebotomines captured. Also found was Nyssomyia whitmani, the vector of tegumentary leishmaniasis. Abundance was greatest in the vicinity of households (69.8\% of the phlebotomines captured). As revealed by PCR, parasites were present in $1.9 \%$ of the Leishmania spp. specimens investigated and confirmed for visceral leishmaniasis.
\end{abstract}

(c) 2008 Elsevier Inc. All rights reserved.

\section{Introduction}

Leishmaniases-zoonoses caused by protozoans of the genus Leishmania-have been the object of considerable attention of both human and veterinary medicine (Barata et al., 2004). Visceral leishmaniasis is a serious chronic disease potentially fatal to humans and its lethality can be as high as $10 \%$, unless suitable treatment is provided (Gontijo and Melo, 2004).

In many areas, leishmaniasis involves a number of animal reservoirs, whereas in some areas humans are the only infection reservoirs, making the control of both vector and reservoirs costly and even unfeasible. The geographical distribution of the disease has changed in recent years, with cases being reported from previously non-endemic areas (World Health Organization, 2002).

Forest clear-cuttings, associated with urbanization, have had a marked influence on vector populations and disease transmission. While some species may have disappeared, others have become more abundant (Bejarano et al., 2002).

In the Americas, $15 \mathrm{New}$ World Leishmania species, grouped into three complexes, are responsible for tegumentary and diffuse cutaneous leishmaniasis (Leishmania mexicana complex), tegumentary leishmaniasis and, frequently, mucocutaneous lesions (Leish-

\footnotetext{
* Corresponding author.

E-mail address: andreott@cnpgc.embrapa.br (R. Andreotti).
}

mania braziliensis complex), in addition to the visceral form of the disease (Leishmania donovani complex) (Grimaldi and Tesh, 1993). Eco-epidemiological studies conducted in various regions of Latin America, particularly in Brazil, culminated in the present recognition of no less than 20 named species of neotropical Leishmania, 14 of which are known to infect humans (Lainson, 1997).

Visceral leishmaniasis has a wide distribution in Latin America, from northern Mexico to southern Argentina (Lainson and Rangel, 2005).

Brazil harbors six Leishmania species of subgenera Viannia and Leishmania, responsible for the tegumentary disease in humans. Subgenus Viannia encompasses the species Leishmania (Viannia) braziliensis, Leishmania (Viannia) guyanensis, Leishmania (Viannia) naiffi, Leishmania (Viannia) shawi, and Leishmania (Viannia) lainsoni; subgenus Leishmania is comprised of Leishmania (Leishmania) amazonensis (Gontijo and Carvalho, 2003). Recently, Leishmania (Viannia) lindenberg has been implicated as the etiologic agent of American tegumentary leishmaniasis (ATL) in the northern state of Pará (Brasil, 2007).

In the southwestern state of Mato Grosso do Sul, tegumentary leishmaniasis is caused by Leishmania (Viannia) braziliensis and Leishmania (Leishmania) amazonensis (Dorval et al., 2006; Brasil, 2007); the etiologic agent of visceral leishmaniasis is Leishmania (Leishmania) chagasi (Oliveira et al., 2006a). 
The development of accurate methods for identification of Leishmania species in insect vectors is central to solid epidemiologic studies and effective control measures and treatment (Harris et al., 1998; Paiva et al., 2006).

In recent years, molecular investigations have been conducted based on the use of polymerase chain reaction (PCR) (Paiva et al., 2004), for which an important initial reference is the genome sequence of the microorganism being investigated. The technique is used for diagnosis in humans (Silva et al., 2002), canines (Andrade et al., 2006), and phlebotomines (Aransay et al., 2000; Ramalho-Ortigão et al., 2001; Miranda et al., 2002; Michalsky et al., 2002; Paiva et al., 2006).

In Campo Grande, the capital city of Mato Grosso do Sul, 92.9\% of the phlebotomine sandflies captured from May 2003 to April 2005 were Lutzomyia longipalpis, the vector of visceral leishmaniasis (Silva et al., 2007). The county is an endemic area for this form of the disease, with 165 cases confirmed in 2006 and 11 deaths, in addition and 15 new cases of ATL notified in the same year (Mato Grosso do Sul, 2007). The purpose of this study was to determine the relative abundance of the population of phlebotomines and the presence of Leishmania species in the phlebotomines, based on DNA amplification.

\section{Materials and methods}

\subsection{Study area}

The county of Campo Grande occupies $8096 \mathrm{~km}^{2}$ in the central portion of Mato Grosso do Sul, near the watershed divide of the
Paraná and the Paraguay basins. The coordinates of its central milestone are $20^{\circ} 26^{\prime} 34^{\prime \prime} \mathrm{S}, 54^{\circ} 38^{\prime} 47^{\prime \prime} \mathrm{W}$. Altitudes range from 500 to $675 \mathrm{~m}$ (Campo Grande, 2006). Population in 2006 was estimated at 765,247 (Instituto Brasileiro de Geografia e Estatística, 2006). Climate is predominantly Aw (Köppen's classification)-tropical humid, with wet summers and dry winters. Precipitation is heaviest from October to March, the period when mean temperatures are around $24^{\circ} \mathrm{C}$. June, July, and August are the driest months (Empresa Brasileira de Pesquisa Agropecuária Gado de Corte, 2006).

\subsection{Methods of capture}

Capture sites were chosen so as to cover 16 neighborhoods in the seven urban regions that comprise the entire county. Traps were placed in households and also outdoors, in the vicinity (Fig. 1). Selection of neighborhoods was based on the occurrence of human cases and higher prevalences. In the Segredo region, these were Vila Nasser and Margarida; in the Prosa region, Veraneio; in the Bandeira region, Maria Aparecida; in the Central region, Amambaí. Because the prevalence of human cases was highest in the Anhanduizinho region, as many as five of its neighborhoods were selected-UFMS, Guanandy, Aero-Rancho, Centenário, and Centro-Oeste-as were the Caiobá, Tarumã, and São Conrado neighborhoods in the Lagoa region and Santo Antonio and Panamá in the Imbirussu region. Captures were carried out from $4 \mathrm{pm}$ to $7 \mathrm{am}$ for four consecutive days each month, from October 2005 to September 2006, using CDC-type light traps ( 8 traps per neighborhood, accounting for 128 traps per month).

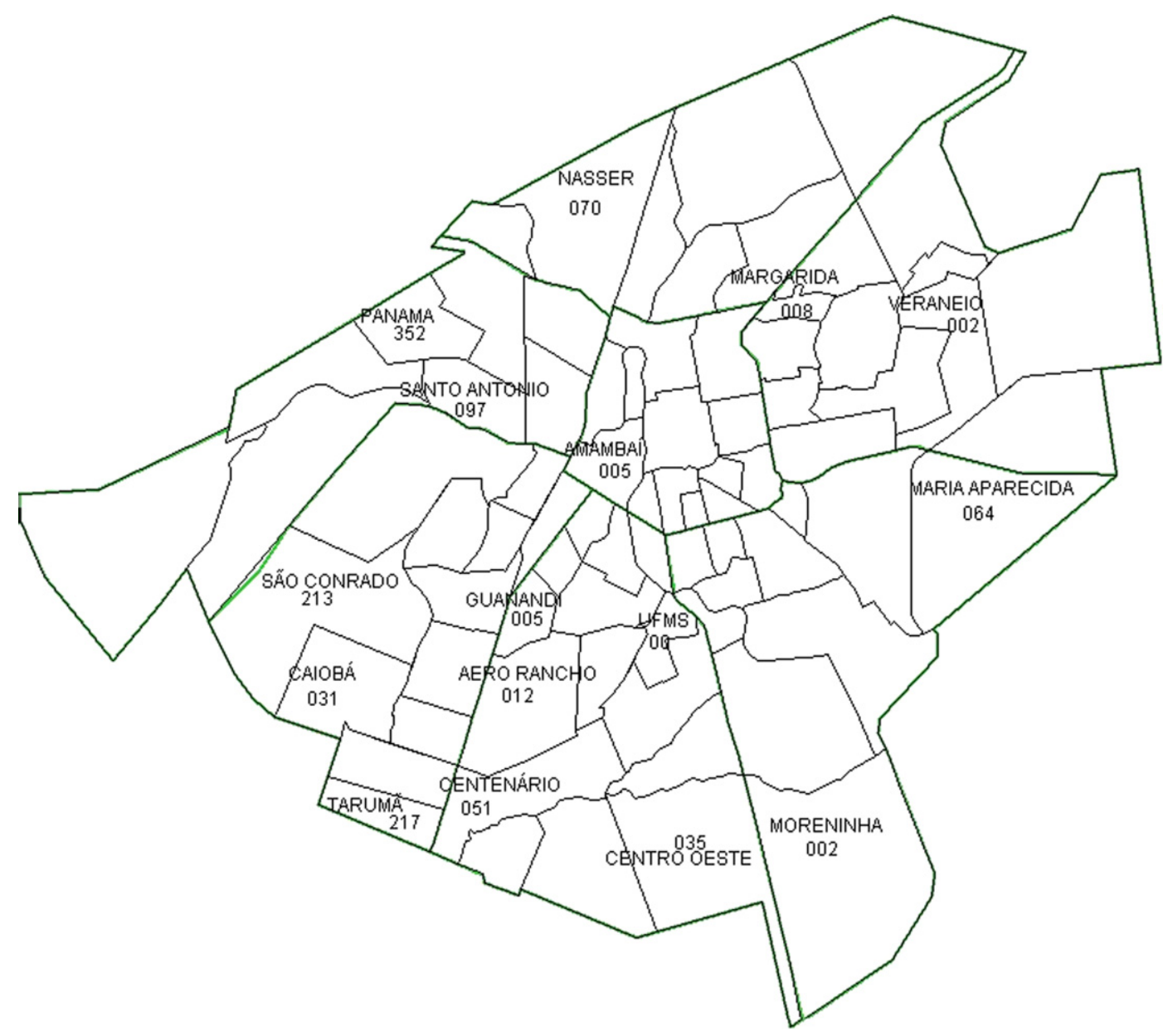

Fig. 1. Campo Grande County, MS, Brazil. Neighborhoods with permanent stations and number of phlebotomine specimens captured in each region. 
Identification of specimens was based on Galati (2003). Females were preserved in tubes containing $70 \%$ ethanol; engorged ones (as detected by visual inspection) were selected for DNA extraction. Males were stored in the entomology laboratory of the Center for Zoonosis Control in Campo Grande.

\subsection{DNA extraction}

Lutzomyia longipalpis females were grouped as 1- to 4-specimen pools, depending on neighborhood, capture site (indoors or in the vicinity of households), and month of capture (Table 2). Extraction was performed using DNAzol kit (Invitrogen, Karlsruhe, Germany), as follows: homogenization of $0.1 \mu \mathrm{L}$ of sample material and $1 \mu \mathrm{L}$ DNAzol, 10-min centrifugation at $12,000 \mathrm{rpm}$, collection of supernatant, precipitation of supernatant with $500 \mu \mathrm{L} 75 \%$ ethanol, second 10 -min centrifugation at $12,000 \mathrm{rpm}$ (supernatant discarded), and addition of $30 \mu \mathrm{L} 8-\mathrm{mM} \mathrm{NaOH}$.

\subsection{DNA amplification}

Amplification was carried out according to Michalsky et al (2002). DNA was amplified in a Mastercycler Personal thermal cycler (Eppendorf, Hamburg, Germany). The assay material was prepared using a mixture of $10 \mu \mathrm{L}$ PCR buffer (100-mM Tris-HCl, 500$\mathrm{mM} \mathrm{KCl}, 15-\mathrm{mM} \mathrm{MgCl}_{2}, \mathrm{pH} 9.0$ ), $5 \mu \mathrm{L}$ dNTPs (all of them $2 \mathrm{mM}$ ), $2 \mu \mathrm{L}$ of each primer $(200 \mathrm{ng} / \mu \mathrm{L}), 0.5 \mu \mathrm{L}$ Taq DNA polymerase $(2.5 \mathrm{U} / \mu \mathrm{L})$, and $26.5 \mu \mathrm{L}$ ultrapure water. Two microliters of DNA $(10 \mathrm{ng} / \mu \mathrm{L})$ were added to each assay. DNA amplification was carried out as described. For Leishmania spp.: primers 5'- GGG GAG GGG CGT TCT GCG AA-3', 5'-CCG CCC CTA TTT TAC ACC AAC CCC$3^{\prime}$, and $5^{\prime}$-GGC CCA CTA TAT TAC ACC AAC CCC-3'; thermocycling: $95{ }^{\circ} \mathrm{C}$ for $5 \mathrm{~min}$, followed by 35 cycles of denaturation $\left(95^{\circ} \mathrm{C}\right.$; $1 \mathrm{~min})$, annealing $\left(60^{\circ} \mathrm{C} ; 1 \mathrm{~min}\right)$, and extension $\left(72^{\circ} \mathrm{C} ; 1 \mathrm{~min}\right)$, with a final extension at $72^{\circ} \mathrm{C}$ for $7 \mathrm{~min}$. For the L. braziliensis complex: primers B1 (5'-GGG GTT GGT GTA ATA TAG TGG-3') and B2 (5'-CTA ATT GTG CAC GGG GAG G-3'); thermocycling: $95^{\circ} \mathrm{C}$ for $5 \mathrm{~min}$, followed by 35 cycles of denaturation $\left(95^{\circ} \mathrm{C} ; 1 \mathrm{~min}\right)$, annealing $\left(55^{\circ} \mathrm{C} ; 1 \mathrm{~min}\right)$, and extension $\left(72^{\circ} \mathrm{C} ; 1 \mathrm{~min}\right)$, with a final extension at $72{ }^{\circ} \mathrm{C}$ for $7 \mathrm{~min}$. For the $L$. mexicana complex: primers M1 ( $5^{\prime}-$ CCA GTT TCG AGC CCC GGA G-3') and M2 (5'-GGT GTA AAA TAG GGG CGG ATG CTC TG-3'); thermocycling: $95{ }^{\circ} \mathrm{C}$ for $5 \mathrm{~min}$, fol- lowed by 35 cycles of denaturation $\left(95^{\circ} \mathrm{C} ; 1 \mathrm{~min}\right)$, annealing $\left(59{ }^{\circ} \mathrm{C} ; 1 \mathrm{~min}\right)$, and extension $\left(72^{\circ} \mathrm{C} ; 1 \mathrm{~min}\right)$, with a final extension at $72{ }^{\circ} \mathrm{C}$ for $7 \mathrm{~min}$.

To identify the L. donovani complex, the samples were also subjected to amplification using primers AJS31 (5'-GGG GTT GGT GTA AAA TAG GGCC-3') and DBY ( $5^{\prime}-$ CCA GTT TCC CGC CCC GGA G-3'); thermocycling: $95^{\circ} \mathrm{C}$ for $5 \mathrm{~min}$, followed by 40 cycles of denaturation $\left(95^{\circ} \mathrm{C} ; 1 \mathrm{~min}\right)$, annealing $\left(61^{\circ} \mathrm{C} ; 1 \mathrm{~min}\right)$, and extension $\left(72{ }^{\circ} \mathrm{C} ; 1 \mathrm{~min}\right.$ ), with a final extension at $72{ }^{\circ} \mathrm{C}$ for $8 \mathrm{~min}$ (Reithinger et al., 2002). They were also subjected to amplification using primers RV1 (5'-CTT TTC TGG TCC CGC GGG TAG G-3') and RV2 (5'-CCA CCT GGC TAT TTT ACA CCA-3'); thermocycling: $94{ }^{\circ} \mathrm{C}$ for $4 \mathrm{~min}$, followed by 40 cycles of denaturation $\left(94^{\circ} \mathrm{C} ; 1 \mathrm{~min}\right)$, annealing $\left(59^{\circ} \mathrm{C} ; 1 \mathrm{~min}\right)$, and extension $\left(72^{\circ} \mathrm{C} ; 1 \mathrm{~min}\right)$, with a final extension at $72{ }^{\circ} \mathrm{C}$ for $7 \mathrm{~min}$ (Lachaud et al., 2002).

DNA controls for all three Leishmania species were provided by the Laboratory of Leishmaniases of Centro de Pesquisas René Rachou-Fiocruz (Belo Horizonte, Brazil)-namely, L. chagasi (MHOM/ $\mathrm{BR} / 74 / \mathrm{PP} / 75$ ), L. braziliensis (MHOM/BR/75/M2903), and L. amazonensis (IPLA/ BR/67/PH8) strains.

\subsection{DNA electrophoresis}

Amplification products were separated in $2 \%$ agarose gel $(6.4 \mathrm{~cm} \times 10 \mathrm{~cm}$ ) (Lachaud et al., 2002) in PBE buffer $(0.089-\mathrm{M}$ Tris- $\mathrm{HCl}, 0.089-\mathrm{M}$ boric acid, 0.02-M EDTA) under $100 \mathrm{~V}$ for $30 \mathrm{~min}$. Bands were visualized under UV after ethidium bromide staining. The gel was documented using a photographic system.

\subsection{Minimum infection rate}

Because the specimens were pooled, a minimum infection rate (MIR) for the insects was calculated as: $M I R=$ number of positive groups $\times 100 /$ total number of insects (Paiva et al., 2006).

\section{Results}

Of the 1174 phlebotomine specimens captured, 203 (17.29\%) were females and 971 (82.71\%) males, with a mean capture rate of 0.76 phlebotomines per trap. Species distribution by month and sex is shown in Table 1 . The species collected were

Table 1

Monthly frequencies of phlebotomine species captured with CDC-type light traps

\begin{tabular}{|c|c|c|c|c|c|c|c|c|c|c|c|c|}
\hline \multirow{2}{*}{$\begin{array}{l}\text { Period } \\
\text { Months }\end{array}$} & \multicolumn{6}{|c|}{ Wet season } & \multicolumn{6}{|c|}{ Dry season } \\
\hline & 0 & $\mathrm{~N}$ & $\mathrm{D}$ & $\mathrm{J}$ & $\mathrm{F}$ & M & A & M & $\mathrm{J}$ & $\mathrm{J}$ & A & $\mathrm{S}$ \\
\hline \multicolumn{13}{|c|}{$\begin{array}{l}\text { Brumptomyia brumpti } \\
\text { M }\end{array}$} \\
\hline \multicolumn{13}{|c|}{ Lutzomyia longipalpis } \\
\hline $\begin{array}{l}\mathrm{M} \\
\mathrm{F}\end{array}$ & $\begin{array}{r}112 \\
12\end{array}$ & $\begin{array}{r}132 \\
6\end{array}$ & $\begin{array}{r}177 \\
21\end{array}$ & $\begin{array}{r}108 \\
10\end{array}$ & $\begin{array}{l}41 \\
36\end{array}$ & $\begin{array}{l}87 \\
29\end{array}$ & $\begin{array}{l}89 \\
33\end{array}$ & $\begin{array}{r}17 \\
7\end{array}$ & $\begin{array}{r}24 \\
5\end{array}$ & $\begin{array}{l}52 \\
13\end{array}$ & $\begin{array}{l}89 \\
18\end{array}$ & $\begin{array}{r}37 \\
9\end{array}$ \\
\hline $\begin{array}{l}\text { Micropyg } \\
\text { M } \\
\text { F }\end{array}$ & & & & & & & 1 & & & & & \\
\hline $\begin{array}{l}\text { Nyssomy } \\
\mathrm{M} \\
\mathrm{F}\end{array}$ & & & 1 & & & & & & & & & \\
\hline $\begin{array}{l}\text { Psathyro } \\
\text { M } \\
\text { F }\end{array}$ & & & 1 & 2 & & 2 & & & & & & \\
\hline $\begin{array}{l}\text { Sciopem } \\
\text { M } \\
\text { F }\end{array}$ & & & & & & & & & & & & 2 \\
\hline Total & 124 & 138 & 200 & 121 & 77 & 118 & 123 & 24 & 29 & 65 & 107 & 48 \\
\hline
\end{tabular}

Campo Grande, Mato Grosso do Sul, Brazil, October 2005-September 2006. 


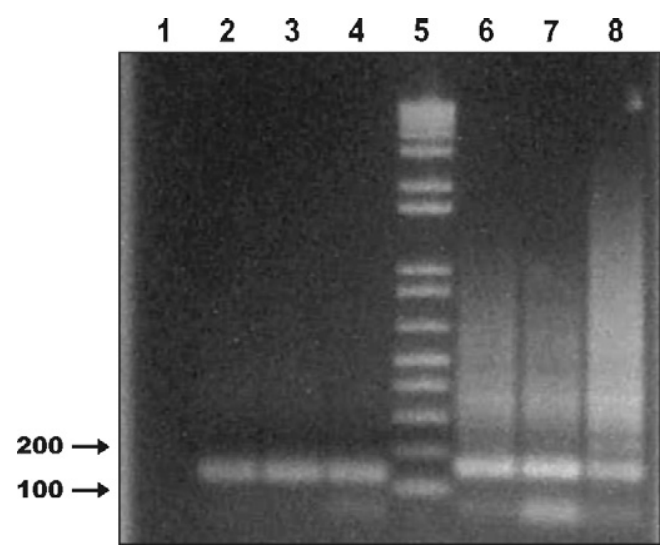

Fig. 2. Results of PCR amplification using primers for the genus Leishmania ( $2 \%$ agarose gel electrophoresis) (Michalsky et al., 2002), yielding a product of around 120 base pairs. 1 , negative control; 2 , positive control; 3 and 4 , positive samples; 5 , molecular markers and primers for L. donovani sensu lato (Lachaud et al., 2002); 6 , positive control; 7 and 8, positive samples yielding a product of around 145 base pairs. Arrows indicate base pair numbers in the marker.

Brumptomyia brumpti, L. longipalpis, Micropygomyia longipennis, Nyssomyia whitmani, Psathyromyia shannoni, and Sciopemyia sordellii. L. longipalpis predominated, accounting for $99.15 \%$ of the phlebotomines captured. One hundred and five naturally fed L. longipalpis females were set aside for DNA extraction for investigation of Leishmania protozoans. In the wetter months, as many as
778 specimens $(66.3 \%)$ were collected; in the drier ones, 396 (Table $1)$.

Densities were highest in the Panamá, Tarumã, and São Conrado neighborhoods, which jointly accounted for $66.6 \%$ of all specimens collected. More phlebotomine specimens were captured in the vicinity of households (822; 70\%) than indoors (352) (Table 3 ).

The primers used by Michalsky et al. (2002) for Leishmania spp. were applied to the 38 DNA groups extracted from the insects. Amplification occurred in one 2-specimen and one 3-specimen sample, yielding a product of around 120 base pairs (Fig. 2). The specimens pooled into these two samples had been captured indoors in the Tarumã neighborhood (Table 2). The same samples amplified DNA when RV1-RV2 primers were used (Lachaud et al., 2002), showing a product of around 145 base pairs (Fig. 2).

Primers B1-B2 and M1-M2, which correspond to the Leishmania braziliensis and Leishmania mexicana complexes, respectively, failed to produce amplification. The same occurred when primers AJS31 and DBY, for the Leishmania donovani complex, were used.

\section{Discussion}

Population density was highest for L. longipalpis in the 16 neighborhoods investigated, accounting for $99.15 \%$ of the phlebotomines captured. The species predominates also in other Brazilian counties, such as Jequié (Dias-Lima et al., 2003), Belo Horizonte (Souza et al., 2004), and Montes Claros (Monteiro et al., 2005), at 98.95\%,

Table 2

Female phlebotomines subjected to PCR extraction, by number of specimens, month, trap location, and results

\begin{tabular}{|c|c|c|c|c|c|}
\hline Sample & Neighborhood & Number of phlebotomines & Month & Trap location & Result \\
\hline 01 & Panamá & 4 & October 2005 & Outdoors & Negative \\
\hline 02 & Panamá & 3 & October 2005 & Outdoors & Negative \\
\hline 03 & Caiobá & 2 & October 2005 & Outdoors & Negative \\
\hline 04 & Centenário & 3 & October 2005 & Indoors & Negative \\
\hline 05 & Santo Antônio & 2 & November 2005 & Indoors & Negative \\
\hline 06 & Tarumã & 3 & November 2005 & Outdoors & Negative \\
\hline 07 & Panamá & 4 & December 2005 & Indoors & Negative \\
\hline 08 & Centenário & 3 & December 2005 & Indoors & Negative \\
\hline 09 & São Conrado & 4 & December 2005 & Outdoors & Negative \\
\hline 10 & V. Nasser & 4 & January 2006 & Indoors & Negative \\
\hline 11 & Santo Antônio & 3 & January 2006 & Outdoors & Negative \\
\hline 12 & Centro-Oeste & 1 & January 2006 & Indoors & Negative \\
\hline 13 & Moreninhas & 1 & February 2006 & Outdoors & Negative \\
\hline 14 & V. Nasser & 4 & February 2006 & Outdoors & Negative \\
\hline 15 & V. Nasser & 3 & February 2006 & Outdoors & Negative \\
\hline 16 & Panamá & 4 & February 2006 & Indoors & Negative \\
\hline 17 & Caiobá & 1 & February 2006 & Indoors & Negative \\
\hline 18 & Margarida & 1 & February 2006 & Indoors & Negative \\
\hline 19 & Maria Aparecida & 4 & February 2006 & Outdoors & Negative \\
\hline 20 & Maria Aparecida & 4 & March 2006 & Indoors & Negative \\
\hline 21 & Guanandy & 1 & March 2006 & Outdoors & Negative \\
\hline 22 & V. Nasser & 1 & March 2006 & Indoors & Negative \\
\hline 23 & Centro-Oeste & 1 & March 2006 & Outdoors & Negative \\
\hline 24 & Panamá & 4 & April 2006 & Outdoors & Negative \\
\hline 25 & Tarumã & 2 & March 2006 & Indoors & Positive \\
\hline 26 & São Conrado & 4 & March 2006 & Indoors & Negative \\
\hline 27 & Aero-Rancho & 4 & April 2006 & Indoors & Negative \\
\hline 28 & V.Nasser & 4 & April 2006 & Outdoors & Negative \\
\hline 29 & Santo Antônio & 2 & September 2006 & Outdoors & Negative \\
\hline 30 & São Conrado & 4 & April 2006 & Outdoors & Negative \\
\hline 31 & Panamá & 4 & April 2006 & Outdoors & Negative \\
\hline 32 & Maria Aparecida & 2 & April 2006 & Indoors & Negative \\
\hline 33 & São Conrado & 2 & May 2006 & Indoors & Negative \\
\hline 34 & São Conrado & 2 & July 2006 & Outdoors & Negative \\
\hline 35 & Maria Aparecida & 2 & July 2006 & Outdoors & Negative \\
\hline 36 & Centenário & 2 & August 2006 & Outdoors & Negative \\
\hline 37 & Tarumã & 3 & August 2006 & Indoors & Positive \\
\hline 38 & Panamá & 3 & September 2006 & Outdoors & Negative \\
\hline
\end{tabular}

Campo Grande, Mato Grosso do Sul, Brazil, October 2005-September 2006. 
Table 3

Number of captured Lutzomyia longipalpis specimens, by trap location (indoors or in the vicinity of households)

\begin{tabular}{lcc}
\hline Month & Indoors & Outdoors \\
\hline October 2005 & 29 & 95 \\
November & 9 & 129 \\
December & 72 & 126 \\
January 2006 & 19 & 99 \\
February & 48 & 29 \\
March & 50 & 66 \\
April & 19 & 103 \\
May & 1 & 23 \\
June & 5 & 24 \\
July & 35 & 30 \\
August & 54 & 53 \\
September & 11 & 35 \\
Total & 352 & 812 \\
\hline
\end{tabular}

Campo Grande, Mato Grosso do Sul, Brazil, October 2005-September 2006.

$68.23 \%$ and $74.1 \%$, respectively, of the total number of specimens captured.

In the Tarumã neighborhood, where the two samples positive for the Leishmania complex were collected indoors, as many as 342 dogs (31.8\% of 1077 ) tested positive in the same year. Five human cases were reported (Campo Grande, 2007). The minimum rate of infection by Leishmania in phlebotomines was 1.9.

Another species of epidemiological importance was N. whitman$i$, vector of Leishmania (Viannia) braziliensis (Gontijo and Carvalho, 2003), previously found by Oliveira et al. (2006b) at low density in a residential area (two specimens) and at a higher density in a forested area (11 specimens). In the cases of tegumentary leishmaniasis notified in Campo Grande, infection probably took place in the rural areas of other counties, though the possibility of infection within the city's urban area cannot be ruled out.

Additional species identified were B. brumpti, M. longipennis, P. shannoni, and S. sordellii, none of which have thus far been implicated as Leishmania vectors.

A male-to-female ratio of $4.8: 1$ was found for L. longipalpis, whereas other studies revealed ratios of 3.6:1 in the same county (Silva et al., 2007) and 4.1:1 in Varzelândia, Minas Gerais (Dias et al., 2007). Most captures occurred in the vicinity of households $(69.76 \%)$, but in two pools comprised of two and three Leishmania-positive specimens the insects were captured indoors, in Tarumã (Lagoa region), one of the neighborhoods where cases in humans and dogs are in high numbers.

Michalsky et al. (2002) evaluated the use of PCR to detect the presence of Leishmania sp. in L. longipalpis and Lutzomyia migonei. Infection was experimental and the samples subjected to PCR came from the same specimen. For studies on natural infection, some investigators have chosen to operate with pools comprised of 2 to 12 insects (Jorquera et al., 2005), 10 (e.g., Oliveira-Pereira et al., 2006), or 1 to 17 (e.g., Paiva et al., 2006).

In the present study, it was not possible to identify the Leishmania complex who's DNA was amplified from the material obtained from phlebotomines, although DNA amplification with primers led to identification of the genus Leishmania. Reithinger et al. (2002) showed that amplifications with primers AJS31 and DBY were feasible for the $L$. donovani complex. In the present investigation, the proportion of positive samples identified by PCR varied considerably among phlebotomines, suggesting that PCR sensitivity may be dependent on parasite load.

Primers RV1-RV2 targeting the highly repetitive kinetoplast DNA for L. donovani sensu lato (L. infantum, L. chagasi, and L. donovani) proved extremely sensitive, detecting 0.2 to 1 parasite per mol of blood in the assays performed by Lachaud et al. (2002). The present assay, in addition to identifying genus in two amplified samples (Reithinger et al., 2002)-as also achieved using primers
RV1-RV2-yielded a higher degree of detail, allowing samples to be identified as belonging to visceral leishmaniasis agents (Lachaud et al., 2002). It can thus be hypothesized that in the present study, PCR sensitivity was high enough for genus identification and for $L$. donovani sensu lato, but failed to produce amplification when primers AJS31 and DBY were used to identify the L. donovani complex.

In the present study, the rate of natural infection of phlebotomines, as revealed by PCR $(1.9 \%)$ was similar to that determined by Oliveira-Pereira et al. (2006), of $0.8 \%$ for $N$. whitmani in the northern state of Maranhão, and to that of 3.9\% reported by Paiva et al. (2006) for Leishmania (Leishmania) chagasi and Leishmania (Leishmania) amazonensis.

Nascimento et al. (2007) focused on data on phlebotomines from three indigenous villages in the rural area of Antônio João County, located on the border between Brazil and Paraguay, $301 \mathrm{~km}$ away from Campo Grande. This investigation instead was conducted in Campo Grande, within the urban perimeter of a county with a population of 765,247 . Campo Grande, the capital city of the state of Mato Grosso do Sul, has been since 2002 an area where transmission rate is high, characterizing an epidemic situation, with 165 confirmed human cases and 11 deaths, in addition to a $16 \%$ seroprevalence rate in dogs in 2007 , for an estimated canine population of 118,200 in that year. The areas focused in each study not only represent very different realities; Campo Grande has been playing an ever-increasing role as a corridor for social and commercial relations in South America (Mato Grosso do Sul, 2007).

The fact that phlebotomines carrying the parasite were collected indoors in a region where human cases of the disease have occurred and seropositive dogs have been found suggests that transmission may be taking place also indoors. Measures for the control of these phlebotomines should therefore be improved.

\section{References}

Andrade, H., Reis, A.B., Santos, S.L., Volpini, A.C., Marques, M.J., Romanha, A.J., 2006. Use of PCR-RFLP to identify Leishmania species in naturally-infected dogs. Veterinary Parasitology 140, 231-238.

Aransay, A.M., Scoulica, E., Tselentis, Y., 2000. Detection and identification of Leishmania DNA within naturally infected sand flies by seminested PCR on minicircle kinetoplastic DNA. Applied and Environmental Microbiology 66, 1933-1938.

Barata, R.A., Silva, J.C.F., Costa, R.T., Fortes-Dias, C.L., Silva, J.C., Paula, E.V., Prata, A. Monteiro, E.M., Dias, E.S., 2004. Phlebotomine sand flies in Porteirinha, an area of American visceral leishmaniasis transmission in the State of Minas Gerais, Brazil. Memórias do Institutot Oswaldo Cruz 99, 481-487.

Bejarano, E.E., Uribe, S., Rojas, W., Vélez, I.D., 2002. Phlebotomine sand flies (Diptera: Psychodidae) associated with the appearance of urban leishmaniasis in the city of Sincelejo, Colombia. Memórias do Instituto Oswaldo Cruz 97, 645647.

Brasil. Ministério da Saúde. 2007. Manual de vigilância e controle da leishmaniose tegumentar/Ministério da Saúde, Secretaria de Vigilância em Saúde, Departamento de Vigilância Epidemiológica. Brasília: Ministério da Saúde.

Campo Grande. Prefeitura Municipal de Campo Grande. 2006. Perfil SócioEconômico de Campo Grande. Planurb.

Campo Grande. Prefeitura Municipal de Campo Grande. 2007. Secretaria de Saúde Pública. Coordenadoria de Vigilância em Saúde. Relatório anual.

Dias, E.D., França-Silva, J.C., Silva, J.C., Monteiro, E.M., Paula, K.M., Gonçalves, C.M., Barata, R.A., 2007. Flebotomíneos (Diptera: Psychodidae) de um foco de leishmaniose tegumentar no Estado de Minas Gerais. Revista da Sociedade Brasileira de Medicina Tropical 40, 49-52.

Dias-Lima, A.G., Guedes, M.L.S., Sherlock, I.A., 2003. Horizontal stratification of the sand fly fauna (Diptera: Psychodidae) in a transitional vegetation between caatinga and tropical rain forest, State of Bahia, Brazil. Memórias do Instituto Oswaldo Cruz 98 (6), 733-737.

Dorval, M.E.M.C., Oshiro, E.T., Cupollilo, E., Castro, A.C.C.C., Alves, T.P., 2006. Ocorrência de leishmaniose tegumentar americana no Estado do Mato Grosso do Sul associada à infecção por Leishmania (Leishmania) amazonensis. Revista da Sociedade Brasileira de Medicina Tropical 39, 43-46.

Empresa Brasileira de Pesquisa Agropecuária Gado de Corte, 2006. Relatório anual 2005-2006. Estação Meteorológica Embrapa-INMET. Campo Grande, MS.

Galati, E.A.B., 2003. Classificação de Phlebotominae. In: Rangel, E.F., Lainson, R. (Eds.), Flebotomíneos do Brasil. Fiocruz, Rio de Janeiro, pp. 53-126.

Grimaldi, G.J., Tesh, R.B., 1993. Leishmaniases of the new world: current concepts and implications for future research. Journal of Clinical Microbiology 6, 230250. 
Gontijo, B., Carvalho, M.L.R., 2003. Leishmaniose tegumentar americana. Revista da Sociedade Brasileira de Medicina Tropical 36, 71-80.

Gontijo, C.M.F., Melo, N.M., 2004. Leishmaniose visceral no Brasil: quadro atual, desafios e perspectivas. Revista Brasileira de Epidemiologia 7, 338-346.

Harris, E., Kropp, G., Bellli, A., Rodriguez, B., Agabian, N., 1998. Single-step multiplex PCR assay characterization of new world Leishmania complexes. Journal of Clinical Microbiology 36, 1989-1995.

Instituto Brasileiro de Geografia e Estatística. IBGE cidades 2006. Available from: http://www.ibge.gov.br/home/ Acess: 28/05/2007.

Jorquera, A., Gonçalez, R., Marchan-Marcano, E., Oviedo, M., Matos, M., 2005. Multiplex-PCR for detection of natural Leishmania infection in Lutzomyia spp. Captures in an endemic region for cutaneous leishmaniasis in state of Sucre, Venezuela. Memórias do Instituto Oswaldo Cruz 100, 45-48.

Lachaud, L., Marchergui-Hammami, S., Chabbert, E., Dereure, J., Dedet, J.P., Bastien, P., 2002. Comparison of six PCR methods using peripheral blood for detection on canine visceral leishmaniasis. Journal of Clinical Microbiology 40, 210-215.

Lainson, R., 1997. On Leishmania enriettii and other enigmatic Leishmania species of the Neotropics. Memórias do Instituto Oswaldo Cruz 92, 377-387.

Lainson, R., Rangel, E.F., 2005. Lutzomyia longipalpis and the eco-epidemiology of American visceral leishmaniasis (LVA) in Brazil. Memórias do Institutot Oswaldo Cruz 100, 811-827.

Mato Grosso do Sul. Governo do Estado de Mato Grosso do Sul. Secretaria de Estado de Saúde. SINAN/MS. Acess: 22/08/2007. Available from: http:// www.saúde.ms.gov.br/.

Michalsky, E.M., Fortes-Dias, C.L., Pimenta, P.F.P., Secundino, N.F.C., Dias, E.S., 2002. Assessment of PCR in the detection of Leishmania spp in experimentally infected individual phlebotomine sandflies (Diptera: Psychodidae: Plebotominae). Revista do Instituto de Medicina Tropical de São Paulo 44, 255-259.

Miranda, J.C., Reis, E., Schriefer, A., Gonçalves, M., Reis, M.G., Carvalho, L., Fernandes, O., Barral-Netto, M., Barral, A., 2002. Frequency of infection of Lutzomyia Phlebotomines with Leishmania braziliensis in a Brazilian endemic area as assessed by pinpoint capture and polymerase chain reaction. Memórias do Instituto t Oswaldo Cruz 97, 185-188.

Monteiro, E.M., Silva, J.C.F., Costa, R.T., Costa, D.C., Barata, R.A., Paula, E.V., MachadoCoelho, G.L.L., Rocha, M.F., Fortes-Dias, C.L., Dias, E.S., 2005. Leishmaniose visceral: estudo de flebotomíneos e infecção canina em Monte Claros, Minas Gerais. Revista da Sociedade Brasisleira de Medicina Tropical 38, 147-152.

Nascimento, J.C., Paiva, B.R., Malafronte, R.S., Fernandes, W.D., Galati, E.A.B., 2007. Natural infection of phlebotomines (Díptera: Psychodidae) in a visceralleishmaniasis focus in Mato Grosso do Sul, Brazil. Revista do Instituto de Medicina Tropical de São Paulo 49, 119-122.

Oliveira, A.L.L., Paniago, A.M.M., Dorval, M.E.C., Oshiro, E.T., Leal, C.R., Sanches, M., Cunha, R.V., Bois, M.N., 2006a. Foco emergente de leishmaniose visceral em
Mato Grosso do Sul. Revista da Sociedade Brasileira de Medicina Tropical 39, 446-450.

Oliveira, A.G., Galati, E.A.B., Oliveira, O., Oliveira, G.R., Espindola, I.A.C., Dorval, M.E.C., Brazil, R.P., 2006b. Abundance of Lutzomyia longipalpis (Diptera: Psychodidae: Phlebotominae) and urban transmission of viscera leishmaniasis in Campo Grande, state of Mato Grosso do Sul, Brazil. Memórias do Instituto Oswaldo Cruz 101, 869-874.

Oliveira-Pereira, Y.N., Rebelo, J.M.M., Moraes, J.L.P., Pereira, S.R.F., 2006. Diagnóstico molecular da taxa de infecção natural de flebotomíneos (Psychodidae, Lutzomyia) por Leishmania sp. na Amazônia maranhense. Revista da Sociedade Brasileira de Medicina Tropical 39, 540-543.

Paiva, B.R., Passos, L.N., Falqueto, A., Malafronte, R.S., Andrade-Junior, H.F, 2004 Single Step Polymerase Chain Reaction (PCR) for the diagnosis of the Leishmania (Viannia) Subgenus. Revista do Instituto de Medicina Tropical de São. Paulo 46, 335-338.

Paiva, B.R., Secundino, N.F.C., Nascimento, J.C., Pimenta, P.F.P., Galati, E.A.B., Andrade Junior, H.F., Malafronte, R.S., 2006. Detection and identification of Leishmania species in field-captured phlebotomine sandflies based on mini-exon gene PCR Acta Tropica 99, 252-259.

Ramalho-Ortigão, J.M., Temporal, P., Oliveira, S.M.P., Barbosa, A.F., Vilela, M.L., Rangel, E.F., Brazil, R.P., Traub-Cseko, Y.M., 2001. Characterization of constitutive and putative differentially expressed mRNAs by means of expressed sequence tags, differential display reverse transcriptase-PCR and randomly amplified polymorphic DNA-PCR from the sand fly vector Lutzomyia longipalpis. Memórias do Instituto Oswaldo Cruz 96, 105-111.

Reithinger, R, Quinnel, RJ Alexander, B. Davies, C.R., 2002. Rapid detection of Leishmania infantum infection in dogs: comparative study using an immunochromatographic dipstick test, enzyme-linked immunosorbent assay and PCR. Journal of Clinical Microbiology 40, 2352-2356.

Silva, E.A., Andreotti, R., Honer, M.R., 2007. Comportamento de Lutzomyia longipalpis, vetor principal da leishmaniose visceral americana, em Campo Grande, Estado de Mato Grosso do Sul. Revista da Sociedade Brasileira de Medicina Tropical 40 (4), 420-425.

Silva, E.S., Pacheco, R.S., Gontijo, C.M.F., Carvalho, I.R., Brazil, R.P., 2002. Visceral Leishmaniasis caused by Leishmania (Viannia) braziliensis in a patient infected with human immunodeficiency virus. Revista do Instituto de Medicina Tropical de São Paulo 44, 145-149.

Souza, C.M., Pessanha, J.E., Barata, R.A., Monteiro, E.M., Costa, D.C., Dias, E.S., 2004. Study on phlebotomine sand fly (Diptera: Psychodidae) fauna in Belo Horizonte, state of Minas Gerais, Brazil. Memórias do Instituto Oswaldo Cruz 99, 795-803.

World Health Organization 2002. Weekly epidemiological record [Internet series]. 44 (77), 365-372. Available from: http//www.who.int/wer/. 